\title{
The Impacts of Intraoperative Ultrasonography Use on Resection Rate in Cases of Brain Tumor
}

\author{
Beyin Tümörü Olgularında Intraoperatif Ultrasonografi Kullanımının Rezeksiyon Oranına Etkisi
}

\author{
(D) Tezcan ÇALIŞKAN, DD Tamer TUNÇKALE \\ Tekirdağ Namık Kemal University Faculty of Medicine, Department of Neurosurgery, Tekirdağ, Turkey
}

\begin{abstract}
Aim: Intraoperative ultrasonography is an accessible and cost-effective monitoring technique that provides a simultaneous view with minimum risk. Despite these advantages, it is still not in use. This study aimed to identify whether the ultrasonography technique would be advantageous for both surgeons in the preoperative period and patient in the postoperative period in cases where intraoperative ultrasonography was used.

Materials and Methods: This retrospective study included data of the cases $(n=113)$ diagnosed with a brain tumor in Tekirdağ Namık Kemal University Hospital between January 01, 2015 and December 31, 2020. The cases operated without using ultrasonography ( $\mathrm{n}=38$ ) formed the control group (group 1), while the cases operated by using ultrasonography $(n=75)$ formed the study group (group 2$)$. In all cases selected randomly, the amount of bleeding during the operation, length of the operation and postoperative stay in the hospital, and residue tumor amount were compared. Data obtained were evaluated statistically. The results were presented in mean \pm standard deviation and/or percentage (frequency). The alpha significance value was accepted as $<0.05$ in intergroup comparisons of the data obtained by being evaluated in the $95 \%$ confidence interval.

Results: The average age of the cases in group 1 was $56.7 \pm 139$ years while it was $57.7 \pm 13.2$ in group 2 . In intergroup comparisons, there was no statistically significant difference $(p>0.05)$ between age $(p=0.61)$, gender $(p=0.74)$, and size of the tumor $(p=0.27)$. It was observed that the average length of the operations of the cases in group 2 was shorter than that of group $1(p=0.03)$, and this result was statistically significant $(p<0.05)$. It was reported that the amount of bleeding of the cases in group 2 was also statistically significant $(p<0.05)$ as against group 1 . The gross total resection rate of cases in group 1 was calculated as 73.7\% while it was 89.3\% in group 2. It was understood that the amount of residue in group 2 compared to group 1 was statistically less $(p<0.05)$ in a significant way $(p=0.03)$. In addition to all these, it was found that the length of stay in group 2 , which included cases operated with ultrasonography, was shorter than in group 1, which included cases operated without using ultrasonography ( $p=0.01$ ).

Conclusion: The use of intraoperative ultrasonography helps the surgeon by identifying resection margin and revealing the relationship between surrounding neural and vascular structures, thus increasing surgical safety. At the same time, the use of ultrasonography decreases the length of operation, amount of bleeding, and length of stay in the hospital, and increases gross total resection rates.
\end{abstract}

Keywords: Brain tumors, intraoperative ultrasound, microsurgery

ÖZ

Amaç: İntraoperatif ultrasonografi eş zamanlı görüntü sağlayan, kolay erişilebilen, minimum riskli ve uygun maliyetli bir görüntüleme tekniğidir. Bu özelliklerine rağmen halen yaygın kullanılmamaktadır. Bu araştırmada intraoperatif ultrasonografi kullanılan olgularda, ultrasonografi tekniğinin hem preoperatif dönemde cerraha hem de postoperatif dönemde olguya faydasının olup olmayacağının araştırılması amaçlandı.

Gereç ve Yöntem: Bu retrospektif araştırmaya 01 Ocak 2015 ve 31 Aralık 2020 tarihleri arasında, Tekirdağ Namık Kemal Üniversite Hastanesi'nde beyin tümörü tanısı alan olgulara $(n=113)$ ait veriler dahil edildi. Ultrasonografi kullanılmadan opere edilen olgular ( $n=38)$ kontrol grubunu (grup 1) oluşturuyorken, ultrasonografi kullanılarak opere edilen olgular $(n=75)$ çalışma grubunu (grup 2) oluşturdu. Randomize olarak seçilen tüm olgularda, cerrahi esnasında gözlemlenen kanama miktarları, cerrahi süreleri ile postoperatif hastanede kalış süreleri ve rezidü tümör miktarları karşılaştırıldı. Elde edilen veriler istatistiksel olarak değerlendirildi. Sonuçlar ortalama \pm standart sapma ve/veya yüzde (frekans) cinsinden sunuldu. \%95 güven aralığında değerlendirilerek elde edilen verilerin gruplar arası karşılaştırmalarında, alfa anlamlılık değeri <0,05 olarak kabul edildi.

Address for Correspondence: Tezcan ÇALIŞKAN MD, Tekirdağ Namık Kemal University Faculty of Medicine, Department of Neurosurgery, Tekirdağ, Turkey Phone: +90 5057647387 E-mail: dtzcan_07@hotmail.com ORCID ID: orcid.org/0000-0001-7735-0584

Received: 25.02.2021 Accepted: 20.05.2021

๑Copyright 2021 by the Tekirdağ Namık Kemal University Faculty of Medicine / Namık Kemal Medical Journal published by Galenos Publishing House. 


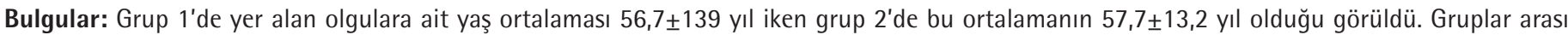
karşılaştırmalarda yaş $(p=0,61)$, cinsiyet $(p=0,74)$ ve tümör büyüklükleri $(p=0,27)$ açısından herhangi bir istatistiksel anlamlılık görülmedi ( $>>0,05)$. Grup 1'e oranla grup 2'de yer alan olguların cerrahi süre ortalamasının daha az olduğu $(p=0,03)$ ve bu sonucun istatistiksel olarak anlamlı olduğu gözlemlendi $(p<0,05)$. Grup 1'e oranla grup 2'de yer alan olgulara ait kanama miktarlarının da yine istatistiksel olarak anlamlı olduğu raporlandı $(p<0,05)$. Grup 1'de yer alan olgularda gross total rezeksiyon oranı \%73,7 olarak hesaplanırken grup 2'de bu oranın \%89,3 olduğu görüldü. Grup 2'de rezidü miktarının grup 1'e oranla istatistiksel olarak anlamlı derecede $(p=0,03)$ daha az olduğu anlaşıldı $(p<0,05)$. Tüm bunlara ek olarak ultrasonografi kullanılan olguların yer aldığı grup 2'deki olguların hastanede kalış süresinin, ultrasonografi kullanılmayarak opere edilen grup 1'de yer alan olgulara oranla daha az sürede olduğu anlaşıldı $(p=0,01)$.

Sonuç: İntraoperatif ultrasonografi kullanımı ile rezeksiyon sınırı belirleme, çevre nöral ve damarsal yapılarla ilişkiyi ortaya koyarak cerraha yardımcı olup, cerrahi güvenliği artırmaktadır. Aynı zamanda ultrasonografi kullanımı cerrahi süreyi, kanama miktarını, hastanede kalış sürelerini azaltmakta ve gross total rezeksiyon oranlarını artırmaktadır.

Anahtar Kelimeler: Beyin tümörleri, intraoperatif ultrason, mikrocerrahi

\section{INTRODUCTION}

Today, thanks to the widespread use of conventional imaging studies and the development of microsurgical methods, mortality and morbidity rates in neurosurgery operations have decreased significantly. With the use of computerized tomography (CT) and the development of magnetic resonance imaging (MRI) technology, the anatomical location and dimensions of the tumor have been revealed more clearly and tumor resection has begun to be performed at surgical margins'.

The earliest use of diagnostic ultrasonography (USG) to detect brain tumors was in the 1930 s by the Dussik brothers ${ }^{2}$. At similar times, the rate of development of intracranial imaging was slowed by the thought that ultrasound waves could damage tissue ${ }^{2}$.

Leksell described midline encephalography in 1956 and used the shift in echo signals in midline structures to detect mass lesions such as hematomas ${ }^{3}$. Thus, intraoperative ultrasonography (IOUS) started to be used in the field of neurosurgery, but it did not become widespread. It is known that the factor that increases the disease-free survival the most in tumor surgery is gross total resection (GTR). GTR is one of the techniques based on the surgeon's ability to determine tumor tissue boundaries and features intraoperatively $y^{4,5}$. By providing real-time images, IOUS can be beneficial for the surgeon to plan or follow the tumor excision. IOUS may be more advantageous than navigation or intraoperative MRI in demonstrating certain features of central nervous system tumors due to many reasons such as inexpensiveness and ease of use, as well as repeatability and easy access during surgery.

These advantages have made IOUS the most important alternative in showing tumor resection margins and edges in adult and pediatric patients $s^{6,7}$. Neuronavigation systems sometimes do not allow obtaining real-time images due to changes in tumor and surrounding tissues during surgery ${ }^{8,9}$.
From this point of view, iOUS can enable us to obtain realtime images superior to navigation with the right probe and experienced hands. IOUS is not a new technology. It has recently started to be used more widely with improved image quality and smaller ultrasonography probes ${ }^{7,9}$.

The advantage of IOUS is to determine the location of the corticotomy after craniotomy and to minimize the risk of residue caused by brain shift ${ }^{9}$.

Therefore, in this research, in order to demonstrate the effectiveness and benefits of using IOUS, it was aimed to compare the data of the patients who were operated without using IOUS in their surgery with the data of the cases who were operated using IOUS. In this way, we believe that the surgical experience on the use of IOUS can be transferred.

\section{MATERIALS AND METHODS}

\section{Study Design}

The data of the cases $(n=113)$ diagnosed with brain tumor and operated by two different surgeons in the Neurosurgery Clinic of Tekirdağ Namık Kemal University Hospital between January 01, 2015 and December 31, 2020 were evaluated retrospectively.

In the archive files of the cases included in the study, it was understood that MRI examinations had a strength of 1.5 Tesla. The cases who were operated without using IOUS (Siemens Acuson X300 brand, Cat $\neq 1547 B 05$, Korea) formed the control group and were named group $1(n=38)$. The cases operated using IOUS formed the study group and were named group 2 $(n=75)$. Hospital files and archive images of the cases in both groups were examined. The numerical data obtained during the reporting were recorded in Microsoft Office program (version 10) Word and Excel lists.

The data of the cases whose preoperative and postoperative MRI examinations could not be reached were not included in 
the study and were excluded from the study. For the cases in all groups, demographic data, duration of surgery, amount of bleeding, and length of hospital stay were recorded.

Preoperative brain MRI images and control contrast-enhanced brain MRI scans (Sectra Medical Systems ${ }^{\mathrm{TM}}$, IDS7) displayed within postoperative 24-72 hours of all operated cases were evaluated, and preoperative tumor sizes and postoperative residual tumor volumes were calculated (Figure 1).

Those with contrast enhancement below $0.175 \mathrm{~cm}^{3}$ were considered as GTR, while those with contrast enhancement above $0.175 \mathrm{~cm}^{3}$ were considered as subtotal resection (STR) ${ }^{10}$.

\section{IOUS Technique}

In the use of IOUS, after craniotomy, before the dura is opened, the USG probe is prepared by putting gel in a sterile sheath. By wetting the dura with saline, the localization of the lesion is confirmed and its borders are determined by slow movements without pressing the USG probe in the craniotomy area, and the relationship with the surrounding vascular structures is confirmed with the Doppler USG function (Figure 2).

After tumor resection, an image is taken again with USG to see if there is any residue (Figure 3 ).

USG and surgical microscope images of the cases are stored in digital media. These images were evaluated retrospectively.

\section{Statistical Analysis}

Statistical Package for the Social Sciences (version 24) was used for statistical analysis. In the comparison between groups, the evaluation of whether two samples obtained from quantitative-scale observations came from the same distribution was carried out with the Mann-Whitney $U$ test, which is a parametric test. The chi-square $\left(\chi^{2}\right)$ test was used for comparison of non-parametric testing and other categorical variables. Results were presented as number (n), mean \pm standard deviation, and/or frequency (\%). Alpha significance value was accepted as $<0.05$.

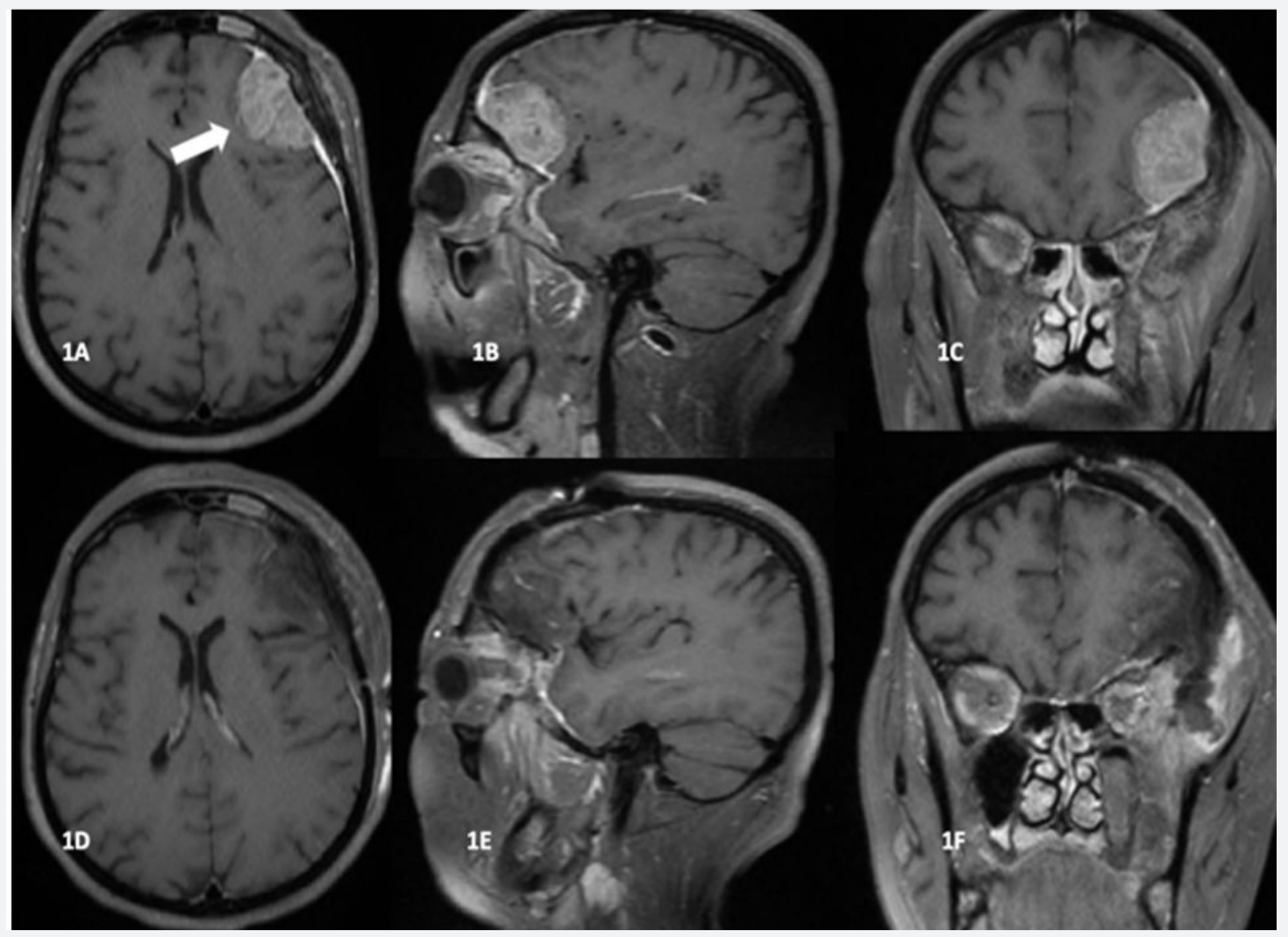

Figure 1. MRI; 1A: In contrast-enhanced T1-weighted sequence axial image, lesion consistent with meningioma with left frontal heterogeneous contrast enhancement (white arrow); 1B: T1-weighted sequence sagittal section shows that the mass is seated on the orbital roof. 1C: T1-weighted sequence, coronal section. 1D: In T1-weighted sequence axial image, it is understood that the mass is totally excised. 1E: T1-weighted sequence, sagittal section image of the same case. 1F: T1-weighted sequence, coronal section 


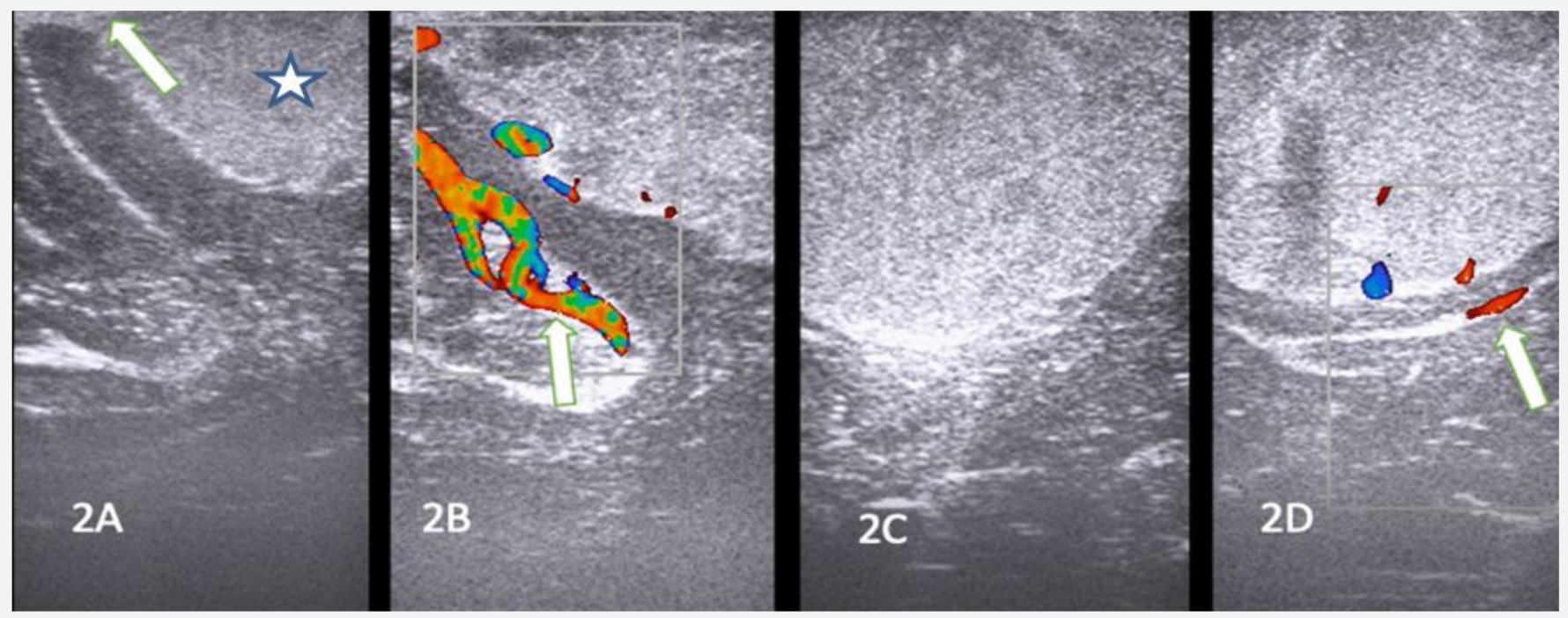

Figure 2. Transdural IOUS images of the same case after craniectomy. 2A: Dural thickening (white arrow), tumoral mass lesion image in the posterior (white star). 2B: In the USG of the same case, vascular structures adjacent to the tumor are observed in the intraoperative Doppler image (white arrow). 2C: Progression of the frontal part of the tumor pushing the brain parenchyma. 2D: Relationship with vascular structures in the frontal part

IOUS: Intraoperative ultrasonography, USG: Ultrasonography

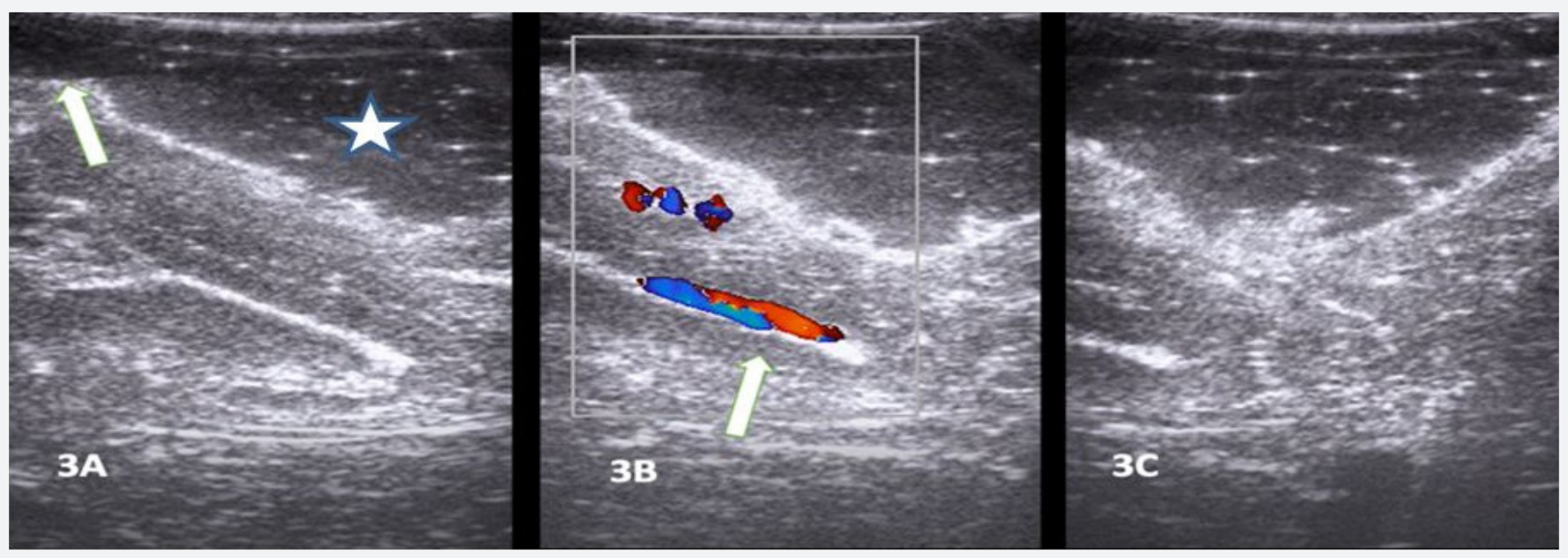

Figure 3. IOUS images after total excision of the tumor; 3A: Anechoic filled saline collection is observed in the extra axial area in the operation lodge (White star). No residual tumor lesion is observed in the images. Normal parenchyma is observed behind the fluid collection. 3B and 3C; Intraoperative Doppler examination reveals vascular structures in the parenchyma (white arrow)

IOUS: Intraoperative ultrasonography

\section{RESULTS}

Group 1 consisted of 18 male and 20 female cases and group 2 consisted of 38 male and 37 female cases. The data of 113 cases included in the study are summarized in Table 1.

While the median age of the cases was 59 years (minimum 20; maximum 86), the mean ages of the cases in group $1(n=38)$ and group $2(n=75)$ were $56.7 \pm 13.9$ and $57.7 \pm 13.2$ years, respectively.

There was no statistically significant difference between the groups in terms of age and gender $(p=0.61 ; p=0.74)$. While the mean tumor size was $28.2 \pm 27.8 \mathrm{~cm}^{3}$ in group 1, it was $34.3 \pm 107.4 \mathrm{~cm}^{3}$ in group 2. Tumor sizes were found to be similar in both groups $(p=0.273)$. 
However, while USG was found to be beneficial in each case in the group using IOUS, it was found that one of the lesions could not be seen in one case. In the patient having lung cancer with multiple metastases, three metastases were found to be removed from the craniotomy area in the postoperative MRI sections. In the pre-closure control of the metastasis adjacent to the midline sagittal sinus, it was noted that the probe did not see the lesion under the bone tissue.

It was reported that the mean surgical time of the cases in group 2 was $276.8 \pm 76.4$ minutes and this time was less than in group 1 , whose mean surgery time was $300.4 \pm 75.9$ minutes $(p=0.03)$.

While the mean amount of bleeding was $482.1 \pm 149.1 \mathrm{cc}$ in group 1, it was $339.7 \pm 1208$ cc in group 2 . Compared to group 1, the amount of bleeding in group 2 was found to be statistically significantly less $(p<0.05)$.

In addition to all these, GTR was detected in 28 cases and STR in 10 cases in group 1, while the rate of GTR was $73.7 \%$. In group 2, 67 cases were evaluated as GTR and eight cases as STR, and the GTR rate was calculated as $89.3 \%$. It was noted that the amount of residue in group 2 was significantly less than in group $1(p=0.03)$.

The histopathological distribution of the cases between the groups is summarized in Table 2.

\section{DISCUSSION}

The purposes of using intraoperative imaging methods are to find the localization of the tumor accurately and precisely and

Table 1. Comparison of demographic, clinical and surgical data of the cases according to the groups with and without ultrasound usage

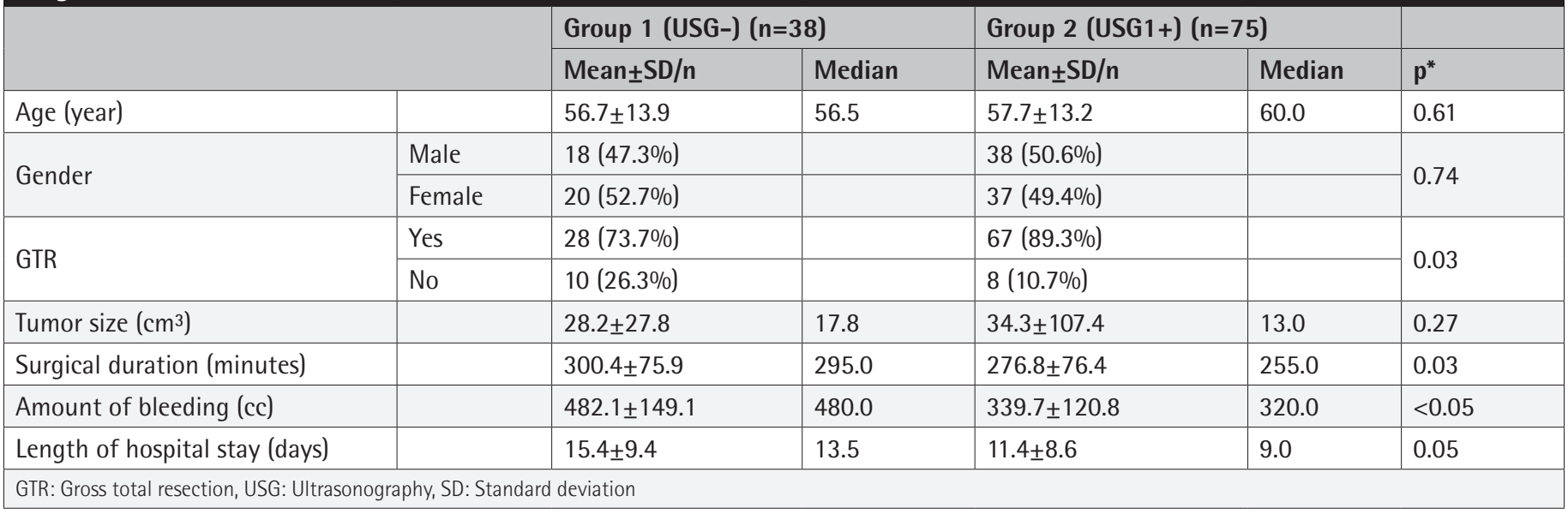

Table 2. Histopathological distribution of the cases between groups

\begin{tabular}{|l|l|l|l|l|}
\hline Pathology & Group 1 & Group 2 & Total number (n) & Frequency (\%) \\
\hline Pilocytic astrocytoma & 1 & 0 & 1 & 0.9 \\
\hline Astrocytoma WHO Grade II & 1 & 3 & 4 & 3.6 \\
\hline Anaplastic astrocytoma & 1 & 3 & 4 & 3.5 \\
\hline GBM & 8 & 19 & 27 & 23.9 \\
\hline Medulloblastoma & 0 & 1 & 1 & 0.9 \\
\hline Atypical teratoid rhabdoid tm & 0 & 1 & 1 & 0.9 \\
\hline Meningioma & 9 & 16 & 25 & 22.1 \\
\hline Schwannoma & 1 & 0 & 1 & 0.9 \\
\hline AC Ca metastasis & 12 & 21 & 33 & 29.1 \\
\hline Breast Ca metastasis & 3 & 5 & 8 & 7.1 \\
\hline GIS-originated metastasis & 1 & 2 & 3 & 2.7 \\
\hline Clear cell Ca & 0 & 1 & 1 & 0.9 \\
\hline Malignant melanoma & 0 & 1 & 1 & 0.9 \\
\hline Epidermoid tumor & 1 & 1 & 2 & 1.8 \\
\hline Lymphoma & 0 & 1 & 1 & 0.9 \\
\hline WHO: World Health Organization, GBM: Glioblastoma, GIS: Gastrointestinal system & & & \\
\hline
\end{tabular}


to distinguish important surrounding structures. USG has been used for diagnostic purposes in various branches for many years. USG, which was firstly used transcranially in the field of neurosurgery, has started to be used widely over time with the developing technology and the reduction in the size of USG probes. Although it is used in many pathologies such as abscess hematoma and hemangioma, its traditional use has been in the field of tumor resection ${ }^{11}$.

On USG images, different pathologies have a diverse and characteristic appearance. Metastatic lesions, meningioma, craniopharyngeoma, hemangioma and acute hemorrhage are seen hyperechogenic. Most glial tumors and edema are seen moderately hyperechogenic. Cystic lesion, necrotic part of high-grade glioma ( $\mathrm{HGG}$ ), center of abscess, chronic hemorrhages and bone are seen hypoechogenic².

USG has been used for maximum safe brain tumor resection since the $1980 \mathrm{~s}^{12}$. Resection margins affect patient survival in $\mathrm{HGG}$, low-grade glioma (LGG), and high-grade meningiomas. Even experienced surgeons can sometimes make a mistake in assessing resection margins. Therefore, ancillary examinations are critical in reliably confirming the margins of intraoperative resection. USG is one of the promising examinations in terms of its providing flexibility and real-time information ${ }^{13,14}$.

Serra et al. ${ }^{15}$ evaluated resection with USG control before closure in a series of 22 high-grade tumors and reported that 95.5\% total resection was achieved.

In the study of Woydt et al. ${ }^{16}$ with 45 patients, 38 of whom had high grade, it was mentioned that the use of IOUS could detect residual tumor with high specificity and thus increase GTR.

Sweeney et al. ${ }^{6}$, in their retrospective cohort analysis study in which they investigated the effect of using IOUS in brain tumor resection, showed that GTR was at the rate of $81 \%$ in cases with different pathologies. A strong correlation was found between IOUS interpretations and postoperative MRI. When the IOUS and postoperative MRI results of the patients who were thought to have STR were examined, they found a $100 \%$ correlation. When the false negative IOUS results in patients who were thought to have GTR were examined, it was seen that some of the cases were related to previous resection, chemotherapy and radiotherapy. They thought that these conditions affected the image resolution ${ }^{6}$.

In this study, USG was found to be beneficial in each case in the case group for whom IOUS was used, but no lesion was observed in one case. In the patient having lung cancer with multiple metastases, three metastases were removed from the craniotomy area, but in the control before the closure of metastasis adjacent to the midline sagittal sinus, it was found that the probe missed the lesion under the bone tissue.
Therefore, we think that craniotomy margins should be kept wide in the use of USG without navigation.

Intraoperative MR imaging, which is one of the intraoperative imaging methods such as USG, has been used in certain centers in recent years. In studies conducted with intraoperative MR, which could not become widespread due to its high cost, it has been stated that intraoperative MRI is superior to twodimensional (2D) IOUS in capturing residues of $1 \mathrm{~cm}^{3}$ and below ${ }^{17,18}$.

However, in the literature, there are studies suggesting that there is a time loss of approximately 10 minutes in each intraoperative MRI and the cost is higher while the application in IOUS does not affect the surgical time ${ }^{18}$.

Mahboob et al. ${ }^{9}$, in their meta-analysis on the use of IOUS in the resection of gliomas, found the mean GTR to be $77 \%$. They reported a compliance rate as $82 \%$ for postoperative MRI and IOUS, false positive IOUS rate as $9 \%$, and false negative IOUS rate as $9 \%{ }^{9}$. In the literature, there are many studies parallel to these results $13,14,18$.

It is reported that the use of IOUS in LGG and HGG increases disease-free survival rates ${ }^{9,19,20}$.

Especially in the surgery of glial tumors, which are intra-axial masses, the tumor is reached by entering through the cortical minimal incision and the tumor is removed through this opening. It can be quite difficult to control the tumor hidden under the cortex with a small cortical incision with standard surgical microscopes.

At this point, USG clears the confusion in the mind of the surgeon, gives important clues about the point where the incision will be made and which direction to go from the small cortical incision, and can provide residual control at the end of the surgery. Thanks to its fast and easy applicability and guidance, it can increase the speed of the surgeon.

In the series evaluated in this study, surgical times were significantly reduced in the group undergoing USG.

Significant decreases in the amount of bleeding and in the length of hospital stay were observed along with the duration of surgery. Making the separation of tumor and glial tissue easily and choosing the closest place to the tumor in the cortical incision reduce the amount of bleeding and glial tissue damage. Decreased blood loss during surgery can be interpreted as the continuation of brain perfusion within physiological limits.

This may reduce the length of hospital stay by causing the physical and cognitive functions of the cases evaluated in this study to improve in the early postoperative period. 
Live mammal subjects can also be used in this type of research ${ }^{21}$. However, it is well known today that the sensitivity of animalderived tissues and human tissue is different ${ }^{22,23}$ and the results obtained from animals can be misleading ${ }^{24,25}$. Data obtained from humans were used in this study. Therefore, we believe that it can contribute to the literature.

\section{Study Limitations}

In the series evaluated in this study, it was observed that the GTR ratio increased significantly and we had results consistent with the literature. However, we think that larger series should be studied in tumors with the same histopathological character in order to reveal the survival rates. This is the first limitation of our study. The second limitation of our study was that the cases from whom the data were obtained were from the same race from a single center. We believe that the findings obtained from multiple centers and different races will be more effective.

\section{CONCLUSION}

In addition to micro-neurosurgical approaches in brain tumor surgery, the use of IOUS can lead to an increase in the GTR rate, a decrease in the surgical time, the amount of bleeding and the length of stay in the hospital, and can take its place among the low-cost, easy-to-use, safe and effective methods. In addition, a short learning curve may be sufficient for image interpretation and usage experience. In the near future, USG may progress to become one of the indispensable equipment of the neurosurgery operating room.

\section{Ethics}

Ethics Committee Approval: The study were approved by the Local Ethics Committee of the Tekirdağ Namık Kemal University (protocol number: 2021.04.01.04, date: 26.01.2021).

Informed Consent: Retrospective study.

Peer-review: Externally peer-reviewed.

\section{Authorship Contributions}

Surgical and Medical Practices: T.Ç., T.T., Concept: T.Ç., T.T., Design: T.Ç., T.T., Data Collection or Processing: T.Ç., T.T., Analysis or Interpretation: T.Ç., T.T., Literature Search: T.Ç., T.T., Writing: T.Ç., T.T.

Conflict of Interest: No conflict of interest was declared by the authors.

Financial Disclosure: The authors declared that this study received no financial support.

\section{References}

1. Regelsberger J, Lohmann $F_{\text {, Helmke }}$, Westphal M. Ultrasound-guided surgery of deep seated brain lesions. Eur J Ultrasound. 2000;12:115-21.

2. Bal J, Camp SJ, Nandi D. The use of ultrasound in intracranial tumor surgery. Acta Neurochir (Wien). 2016;158:1179-85.

3. LEKSELL L. Echo-encephalography. I. Detection of intracranial complications following head injury. Acta Chir Scand. 1956;110:301-15.

4. Chacko AG, Kumar NK, Chacko G, Athyal R, Rajshekhar V. Intraoperative ultrasound in determining the extent of resection of parenchymal brain tumours--a comparative study with computed tomography and histopathology. Acta Neurochir (Wien). 2003;145:743-8.

5. Hammoud MA, Ligon BL, elSouki R, Shi WM, Schomer DF, Sawaya R. Use of intraoperative ultrasound for localizing tumors and determining the extent of resection: a comparative study with magnetic resonance imaging. J Neurosurg. 1996;84:737-41

6. Sweeney JF, Smith H, Taplin A, Perloff E, Adamo MA. Efficacy of intraoperative ultrasonography in neurosurgical tumor resection. J Neurosurg Pediatr. 2018;21:504-10.

7. Pino MA, Imperato A, Musca I, Maugeri R, Giammalva GR, Costantino $G$, et al. New Hope in Brain Glioma Surgery: The Role of Intraoperative Ultrasound. A Review. Brain Sci. 2018;8:202.

8. Gerard IJ, Kersten-Oertel M, Petrecca K, Sirhan D, Hall JA, Collins DL. Brain shift in neuronavigation of brain tumors: A review. Med Image Anal. 2017;35:403-20.

9. Mahboob S, McPhillips R, Qiu Z, Jiang Y, Meggs C, Schiavone G, et al. Intraoperative Ultrasound-Guided Resection of Gliomas: A Meta-Analysis and Review of the Literature. World Neurosurg. 2016;92:255-63.

10. Acerbi $F$, Broggi $M$, Eoli $M$, Anghileri E, Cavallo $C$, Boffano $C$, et al. Is fluorescein-guided technique able to help in resection of high-grade gliomas? Neurosurg Focus. 2014;36:E5.

11. Policicchio D, Doda A, Sgaramella E, Ticca S, Veneziani Santonio F, Boccaletti R. Ultrasound-guided brain surgery: echographic visibility of different pathologies and surgical applications in neurosurgical routine. Acta Neurochir (Wien). 2018;160:1175-85.

12. el Mouaaouy A, Gawlowski J, Schrot G, Arlt R. Die intraoperative Ultraschalldiagnostik in der Neurochirurgie [Intraoperative ultrasound diagnosis in neurosurgery]. Ultraschall Med. 1986;7:235-8.

13. Sastry R, Bi WL, Pieper S, Frisken S, Kapur T, Wells W, et al. Applications of Ultrasound in the Resection of Brain Tumors. J Neuroimaging. 2017;27:515.

14. Hu S, Kang H, Baek Y, El Fakhri G, Kuang A, Choi HS. Real-Time Imaging of Brain Tumor for Image-Guided Surgery. Adv Healthc Mater. 2018;7:e1800066.

15. Serra C, Stauffer A, Actor B, Burkhardt JK, Ulrich NH, Bernays RL, et al. Intraoperative high frequency ultrasound in intracerebral high-grade tumors. Ultraschall Med. 2012;33:E306-12.

16. Woydt M, Krone A, Becker G, Schmidt K, Roggendorf W, Roosen K. Correlation of intra-operative ultrasound with histopathologic findings after tumour resection in supratentorial gliomas. A method to improve gross total tumour resection. Acta Neurochir (Wien). 1996;138:1391-8.

17. Gerganov VM, Samii A, Akbarian A, Stieglitz L, Samii M, Fahlbusch R. Reliability of intraoperative high-resolution 2D ultrasound as an alternative to high-field strength MR imaging for tumor resection control: a prospective comparative study. J Neurosurg. 2009;111:512-9.

18. Erdoğan N, Tucer B, Mavili E, Menkü A, Kurtsoy A. Ultrasound guidance in intracranial tumor resection: correlation with postoperative magnetic resonance findings. Acta Radiol. 2005;46:743-9.

19. Gerganov VM, Samii A, Giordano M, Samii M, Fahlbusch R. Two-dimensional high-end ultrasound imaging compared to intraoperative MRI during resection of low-grade gliomas. J Clin Neurosci. 2011;18:669-73. 
20. Wang J, Liu X, Ba YM, Yang YL, Gao GD, Wang L, et al. Effect of sonographically guided cerebral glioma surgery on survival time. J Ultrasound Med. 2012;31:757-62.

21. Simon RH, Ho SY, Perkins CR, D'Arrigo JS. Quantitative assessment of tumor enhancement by ultrastable lipid-coated microbubbles as a sonographic contrast agent. Invest Radiol. 1992;27:29-34.

22. Karaarslan N, Yilmaz I, Sirin DY. Toxicity of the acetyl-para-aminophenol group of medicines to intact intervertebral disc tissue cells. Exp Ther Med. 2021;21:147.
23. Caliskan T, Sirin DY, Karaarslan N, Yilmaz I, Ozbek H, Akyuva Y, et al. Effects of etanercept, a tumor necrosis factor receptor fusion protein, on primary cell cultures prepared from intact human intervertebral disc tissue. Exp Ther Med. 2019;18:69-76.

24. Yilmaz I, Karaarslan N, Ozbek H. Practical Performance of Hippocampal Tissue Resection in Rats in Pharmacomolecular Research. Turk Neurosurg. 2021;31:112-8.

25. Yilmaz I, Karaarslan N, Yasar Sirin D, Ozbek H. Pharmaco-molecular assessment of the effects of anandamide and its antagonists on hippocampal tissue in Wistar albino rats. Eur Rev Med Pharmacol Sci. 2020;24:11871-82 